\title{
ANALYSIS OF SERUM PROSTATE SPECIFIC ANTIGEN AFTER TURP AND ITS CORRELATION WITH LEVEL OF COMPLETION IN TURP
}

\section{Urology}

Ajay Anand*

\section{Sonam Gupta}

Department of Urology and Surgery, Superspeciality Hospital, Govt. Medical College Hospital, Jammu-180001.*Corresponding Author

Department of Surgery, Govt. Medical College Hospital, Jammu-180001.

\section{ABSTRACT}

Introduction: Patients experience marked decline in serum PSA after TURP; thus PSA behaviour after TURP is crucial during patient follow up. It is known that serum PSA levels increase temporarily in first few days following TURP, decreasing gradually afterwards and reaching stable values within 3-6 months. We conducted study to elucidate fall in serum PSA 3 months after TURP; and also to correlate serum PSA with size of prostate. Methods: The study was conducted in Department of Surgery and Urology, Government Medical College, Jammu from November 2016 till date. During this study period, 40 patients who underwent TURP for benign prostatic hyperplasia were enrolled in study. Serum PSA levels were measured preoperatively and 3 months postoperatively.

Results: The mean decline in serum PSA in benign prostate glands following TURP was $66.06 \%$. Resection of $1 \%$ of prostate tissue resulted in $2.23 \%$ reduction in PSA and resection of one gram of prostate tissue resulted in mean decrease of $0.13 \pm 0.7 \mathrm{ng} / \mathrm{ml}$ in PSA.

Conclusion:There is significant decrease in serum PSA levels after TURP in BPH patients. PSA level after TURP depends on various factors including pre-operative PSA and prostate volume; and prostate volume resected. There is linear relationship between different resection extent of TURP surgery and declination in serum PSA. After complete TURP with benign histopathologic specimen, PSA should be expected to be within normal reference range; mostly near the value of $1 \mathrm{ng} / \mathrm{ml}$. Serum PSA should be monitored at 3 months post TURP to assess the extent of resection of prostate.

\section{KEYWORDS}

PSA, TURP, Correlation, Completion TURP

\section{INTRODUCTION}

PSA behaviour after TURP is crucial during patient follow up. Serum PSA levels increase temporarily in the first few days following TURP, decreasing gradually afterwards and reaching stable values within 3-6 months. 'However serum PSA level stabilization apparently depends on several aspects, which include patient's age, PSA levels and prostate volume before surgery; and prostate volume resected. Vesey et $\mathrm{al}^{2}$ published one of the first studies evaluating the impact of TURP on PSA levels. They found a correlation between prostate size and preoperative PSA, noting that there is temporary rise in PSA levels in the first few days following surgery. Although different factors may affect PSA reduction after the procedure yet an approximate $72 \%$ decrease from baseline is expected, even with a proportionally lower reduction in prostate volume. This occurs because resection affects basically the transition zone of the prostate, which produces more PSA per gram of tissue. ${ }^{3}$ We conducted a study to elucidate fall in serum prostate specific antigen 3 months after transurethral resection of prostate; and also to correlate serum prostate specific antigen with the size of prostate in benign prostatic hyperplasia.

\section{METHODS}

The study was undertaken in the Post Graduate Department of Surgery and Urology, Govt. Medical College Jammu, from November 2016 till date. This was a prospective study. Study followed ethical guidelines and all principles of Helsinki declaration were followed.

Aim of our study was to assess correlation of serum PSA in pre and post transurethral resection of prostate in benign prostatic hyperplasia. 40 patients who underwent TURP for benign prostatic hyperplasia were included in study. Patients with lower urinary tract symptoms associated with benign prostatic hyperplasia with serum PSA $<4 \mathrm{ng} / \mathrm{ml}$ were included. Patients with raised serum PSA $(>4 \mathrm{ng} / \mathrm{ml})$ but normal DRE, normal TRUS and TRUS guided prostatic biopsy showing benign pathology were also included in study. Patients with adenocarcinoma, with atypical small acinar proliferation (ASAP) or intraepithelial neoplasia, cases of BPH with vesical calculus, patients with abnormal DRE finding (asymmetric, nodular or tender prostate) were excluded from study.

Serum PSA levels were measured preoperatively. Transrectal ultrasonography (TRUS) was done to measure size and anatomy of prostate. Patients with serum PSA level $<4 \mathrm{ng} / \mathrm{ml}$, who fulfilled inclusion criteria were randomly selected to undergo transurethral resection of prostate. Repeat Serum PSA levels, urine culture and Transrectal ultrasonography were done at 3 months after surgery. The difference in the preoperative and postoperative Serum PSA levels was evaluated. The results of two groups were analysed and compared with each other.

The resected specimen weight of prostate was compared with changes in serum PSA level using correlation and regression test as statistical methods. Using the above mentioned statistical methods, the formula $y=2.389+0.158 x(x=$ resected specimen weight, $y=$ changes in serum PSA levels) was derived. This was then used to find out changes in serum PSA for resected weight of prostate and $p$ value was calculated to assess statistical significance.

\section{RESULTS}

Majority of patients were in age group of 66-75 years. Mean age of patients was 68 years. Out of 40 patients, 33 patients had severe IPSS score in the range of 20-35; only 7 patients had moderate (8-19) score. Mean IPSS score was 23. 14 patients had indwelling catheter preoperatively. Preoperatively 5 patients whose PSA was $>4 \mathrm{ng} / \mathrm{ml}$ underwent biopsy and were included in study; after histopathology showed benign disease. Out of 40 patients, 33 patients had trilobar anatomy of prostate and 7 patients had bilobar intraoperative anatomy. The mean TRUS size of prostate before procedure was $45 \mathrm{gms}$ $(45.83 \pm 14.05 \mathrm{~g})$ and after procedure, it was $10 \mathrm{gms}(10.85 \pm 3.38 \mathrm{~g})$

The mean serum PSA before TURP was $3.06 \mathrm{ng} / \mathrm{ml}$ and after TURP, it was $1.01 \mathrm{ng} / \mathrm{ml}$. Patients less than 60 years of age had mean PSA 3.55 $\mathrm{ng} / \mathrm{ml}$ before TURP and $1.1 \mathrm{ng} / \mathrm{ml}$ after TURP, as shown in table 1 . Patients more than 60 years of age had mean serum PSA $2.97 \mathrm{ng} / \mathrm{ml}$ before TURP and $1.0 \mathrm{ng} / \mathrm{ml}$ after TURP.

Table 1 - Association between age groups, TRUS size and Serum PSA before and after surgery

\begin{tabular}{|c|c|c|c|c|}
\hline \multirow{2}{*}{$\begin{array}{c}\text { Age } \\
\text { groups } \\
\text { (years) }\end{array}$} & \multicolumn{3}{|c|}{ Mean \pm Standard deviation } \\
\cline { 2 - 5 } & Before procedure & $\begin{array}{c}\text { After } \\
\text { procedure }\end{array}$ & $\begin{array}{c}\text { Serum PSA (ng/ml) } \\
\text { procedure }\end{array}$ & $\begin{array}{c}\text { After } \\
\text { procedure }\end{array}$ \\
\hline$\leq 60$ & $48.50 \pm 6.98$ & $11.00 \pm 1.79$ & $3.55 \pm 2.00$ & $1.10 \pm 0.63$ \\
\hline$>60$ & $45.35 \pm 14.98$ & $10.82 \pm 3.61$ & $2.97 \pm 1.38$ & $1.00 \pm 0.57$ \\
\hline p-value & 0.621 & 0.913 & 0.384 & 0.694 \\
\hline
\end{tabular}

The mean decline in serum PSA in benign prostate glands following TURP was $66.06 \%$ as shown in table 2 .

Table 2 - Mean Serum PSA (ng/ml) decline before and after TURP

\begin{tabular}{|c|c|c|}
\hline \multicolumn{2}{|c|}{ Mean \pm Standard deviation } & $\begin{array}{c}\text { Mean PSA } \\
\text { decline (\%) }\end{array}$ \\
\cline { 1 - 2 } $\begin{array}{c}\text { Serum PSA (ng/ml) before } \\
\text { TUR }\end{array}$ & $\begin{array}{c}\text { Serum PSA (ng/ml) } \\
\text { after TURP }\end{array}$ & \\
\hline $3.06 \pm 1.48$ & $1.01 \pm 0.48$ & 66.06 \\
\hline
\end{tabular}


We noticed a $2.04 \mathrm{ng} / \mathrm{ml}$ decline in serum PSA for every 19.76 gram resected prostatic tissue as shown in Table 3 and figure 1.

Table 3 - Decline in serum PSA for resected weight of prostate \begin{tabular}{|l|l|l|l}
\hline Mean \pm Standard & Recected weight (g) Decline in serum PSA
\end{tabular} \begin{tabular}{l|l} 
Deviation & Rected weight $(\mathrm{g} / \mathrm{ml})$ \\
\hline
\end{tabular}

\begin{tabular}{|l|l|l|}
\hline & & \\
\hline & $19.76 \pm 4.07$ & $2.04 \pm 1.06$ \\
\hline
\end{tabular}

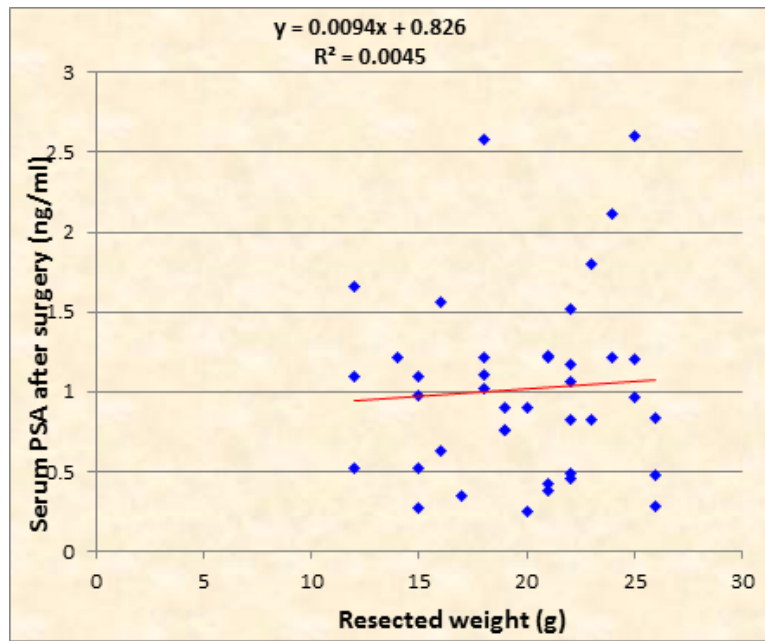

Figure 1 - Scatter diagram showing association between serum PSA level and resected adenoma weight (g) after surgery

Mean PSA declined from $3.06 \pm 1.48$ before TURP to $1.01 \pm 0.48$ after TURP as shown in table 4 and figure 2. This was a statistically significant decrease in serum PSA after TURP.

Table 4 - Serum PSA (ng/ml) before and after procedure

\begin{tabular}{|l|c|c|}
\hline \multirow{2}{*}{ Serum PSA (ng/ml) } & \multicolumn{2}{|c|}{ Mean \pm Standard deviation } \\
\cline { 2 - 3 } & Before procedure & After procedure \\
\cline { 2 - 3 } & $3.06 \pm 1.48$ & $1.01 \pm 0.48$ \\
\hline p-value & \multicolumn{2}{|c|}{$<0.0001$} \\
\hline
\end{tabular}

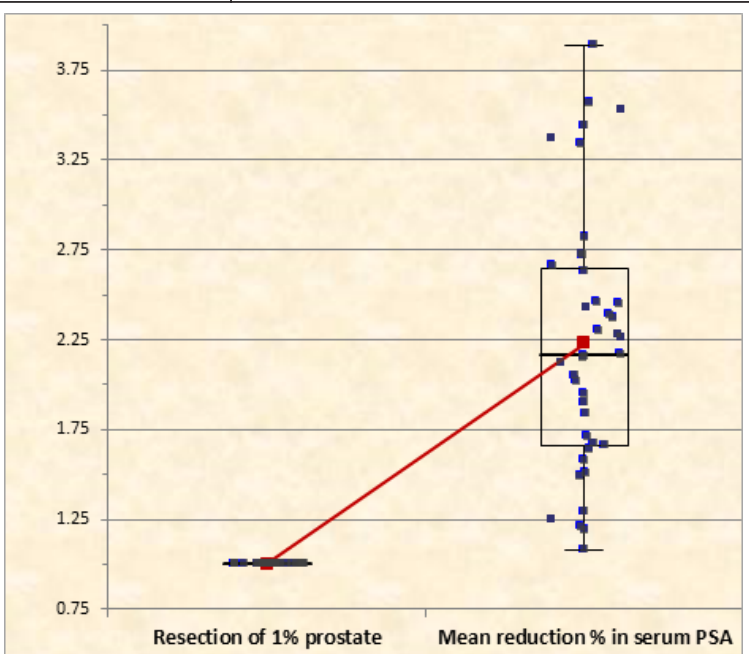

Figure 2 - Decrease in serum PSA after resection of $1 \mathrm{gm}$ of prostate

\section{DISCUSSION}

Roehrborn et $\mathrm{al}^{4}$ had found that serum PSA is closely related to prostate volume. They observed a linear relationship between prostate volume and serum PSA. After resection of an adenoma of prostate, PSA levels are expected to decrease to the reference range. Stamey et $\mathrm{al}^{5}$ demonstrated that after adenectomy for BPH, serum PSA levels were reduced drastically in direct proportion to volume of tissue removed. PSA is a valuable tool in follow up of BPH patients, but it is unknown as to what is the exact behaviour of this marker following TURP; it probably depends on several factors.
We opine that a complete TURP should aim at a postoperative prostate volume of $10 \pm 4$ grams. PSA is directly proportional to prostate volume. It is thus an ideal marker to assess completion TURP postoperatively. In our study, we found a positive correlation with decline in serum PSA following an ideal and complete TURP.

Cho JS et $\mathrm{al}^{6}$ evaluated the same relationship between serum PSA and prostate volume. Cho $\mathrm{HJ} \mathrm{et} \mathrm{al}^{7}$ also found that PSA normalization rate at third month was $94.6 \%$. Both studies concluded that prostate volume and serum PSA have an age-dependent log-linear relationship that is their logarithms are linearly related and the parameters of the relationship depend on age. These findings were also observed in our study.

In our study the mean size of prostate was $45.83 \pm 14.05 \mathrm{~g}$ preoperatively which is related to study conducted by Park SC et al which had mean preoperative prostate size of $52.7 \pm 18.48 \mathrm{~g}$. The post TURP mean TRUS size of prostate was $10.85 \pm 3.38 \mathrm{~g}$ in our study. The difference between the two values was $34.98 \mathrm{~g}$ with $\mathrm{p}$-value of 0.0001 which was very significant. These values are also correlating with study conducted by Aus G et al. ${ }^{1}$ In that study the preoperative prostate volume was $63.3 \mathrm{ml}$ and post TURP volume was $26.6 \mathrm{ml}$. The reduction in gland was 36.7 which is highly significant with p-value of less than 0.0001 . Hence the results are correlating with our study.

In a study conducted by Recker $\mathrm{F}$ et $\mathrm{al}^{9}$, the relation of serum PSA following TURP was evaluated. In this study about $127 \mathrm{BPH}$ patients were included in the study and mean serum PSA before TURP in the patients was $3.43 \mathrm{ng} / \mathrm{ml}$. The mean serum PSA in our study before TURP was $3.06 \mathrm{ng} / \mathrm{ml}$.

Hosseini SY et a ${ }^{10}$ concluded that patients who underwent TURP had a reduction in serum PSA by $67.4 \%$. The reduction in prostate volume was by $54.2 \%$. The PSA reduction per gram of resected adenoma was $0.15 \mathrm{ng} / \mathrm{ml}$ in patients treated with TURP. Won JJ et a ${ }^{11}{ }^{1}$ investigated the relationship between resected prostate specimen weight and serum PSA levels. They concluded that removal of $1 \mathrm{gm}$ of prostate tissue decreased serum PSA by an average of $0.45 \pm 0.25 \mathrm{ng} / \mathrm{ml}$. Fonseca RC et $\mathrm{al}^{12}$ concluded that PSA levels decrease drastically after TURP. Mean PSA before surgery was $6.19 \mathrm{ng} / \mathrm{ml}$, after 60 days it was reduced to $1.75 \mathrm{ng} / \mathrm{ml}$ that is about $71 \%$ reduction. Each gram of resected tissue decreased PSA by $0.15 \mathrm{ng} / \mathrm{ml}$. The $\mathrm{f} / \mathrm{t}$ PSA ratio did not change and the finding of chronic prostatitis did not affect the levels of these variables. Hasibuan $\mathrm{Z}$ et al ${ }^{13}$ concluded that the decrease of serum PSA per gram resected after 60 days following TURP in BPH patients was $0.16 \mathrm{ng} / \mathrm{ml}$. Furuya $\mathrm{Y}$ et $\mathrm{al}^{14}$ investigated 130 patients who underwent transurethral prostatectomy for BHP. Serum PSA levels were measured before and three months after the operation. The concentration of preoperative serum PSA showed a significant correlation with the prostatic volume and with the transition zone volume. Removal of $1 \mathrm{~g}$ of BPH tissue reduced serum PSA levels by an average of $0.18 \mathrm{ng} / \mathrm{ml}$. Renterghem $\mathrm{KV}$ et $\mathrm{al}^{15}$ evaluated 74 patients with elevated serum PSA $(>4 \mathrm{ng} / \mathrm{ml})$ after negative multiple biopsies, who underwent TURP and determined that the mean PSA level decreased from $8.8 \mathrm{ng} / \mathrm{ml}$ before TURP to $1.1 \mathrm{ng} / \mathrm{ml}$ in the first year and $1.3 \mathrm{ng} / \mathrm{ml}$ in the second year after TURP. The data suggested that patients with LUTS and elevated PSA without evidence of Ca prostate are very likely to have bladder outlet obstruction due to BPH.

Our findings were also consistent with their studies. In our study conducted on 40 patients of BPH following 3 months post TURP in GMC Jammu, the mean decline in serum PSA was $66.06 \%$. Our study concluded that resection of $1 \%$ of prostate tissue resulted in $2.23 \%$ reduction in serum PSA and resection of one gram of prostate tissue resulted in mean decrease of $0.13 \pm 0.7 \mathrm{ng} / \mathrm{ml}$ in serum PSA. In patients with $\mathrm{BPH}$, there was a strong statistical correlation and a direct proportionality between the resected specimen weight and changes in the serum PSA levels $(\mathrm{P}<0.05)$.

Wolff JM et al ${ }^{16}$ investigated how transurethral resection of prostate affected the concentration of serum PSA. 55 patients were retrospectively analysed. All had undergone TURP for bladder outlet obstruction due to BPH. PSA was determined pre and postoperatively every 6 months for 48 months. The median PSA concentration was $4.9 \mathrm{ng} / \mathrm{ml}$ before TURP and was subsequently reduced to $0.6 \mathrm{ng} / \mathrm{ml}$ after 48 months. There was a steady decrease of the PSA concentration during the observational period. In contrast in patients who subsequently develop a prostate cancer, the median PSA concentration 
before TURP was $6.8 \mathrm{ng} / \mathrm{ml}$ and was reduced to only $2.2 \mathrm{ng} / \mathrm{ml}$ after 48 months. They concluded that after a TURP with a benign histopathologic specimen, PSA levels decrease steadily to values below $2 \mathrm{ng} / \mathrm{ml}$. In case these patients demonstrate a rising PSA in the follow up after TURP, a prostate cancer should be ruled out. This is also an important aspect to follow-up post TURP patients with serum PSA. Any rise in serum PSA after an initial fall should warrant further investigations to rule out de novo prostate cancer. We are aware that TURP removes transition zone of prostate; whereas peripheral zone of prostate remains intact. As per Mc Neil classification of prostate zones, this peripheral zone is the commonest cause of prostate cancer. In absence of urinary tract infection, failure of fall of serum PSA inspite of completion TURP and normal histopathological findings and/or rise in serum PSA after an initial fall are indicators of missed prostate carcinoma. Such patients need further radiological investigations like mp MRI and guided peripheral zone biopsies to rule out indolent carcinoma.

Koeveringe VG et al ${ }^{17}$ evaluated patients with elevated PSA in whom histological examination after TURP revealed benign prostate hyperplasia. They concluded that preoperatively mean PSA was 8.2 $\mathrm{ng} / \mathrm{ml}$ and mean postoperative PSA was $0.6 \mathrm{ng} / \mathrm{ml}$. This study showed that in patients with LUTS and no suspicion for prostate cancer, bladder outlet obstruction could result in elevated PSA and these patients would benefit from TURP regarding symptomatologically and normalisation of PSA levels. Their series had higher mean serum PSA unlike that in our study. However our findings are consistent with their studies that PSA should decrease significantly after TURP; and this decrease is in consonance with prostate volume resected as also suggested in study by Liu J et al ${ }^{18}$ who evaluated values of serum PSA of 207 patients of BPH before and after TURP. There appears to be a linear relationship between the different resection extent of TURP surgery and the decline in PSA values.

Patients with cut-off value of serum PSA of $<4 \mathrm{ng} / \mathrm{ml}$ were included in our study and all patients with serum PSA $>4 \mathrm{ng} / \mathrm{ml}$ had preoperative prostate biopsy to rule out prostate carcinoma. Mean serum PSA fell from preoperative level of $3.06 \pm 1.48$ to postoperative level of $1.01 \pm$ 0.48 ( $\mathrm{p}$ value $<0.0001$ ) for prostate volume decrease from $45 \mathrm{gms}$ $(45.83 \pm 14.05 \mathrm{~g})$ preoperatively to $10 \mathrm{gms}(10.85 \pm 3.38 \mathrm{~g})$ postoperatively.

\section{CONCLUSION}

There is significant decrease in serum PSA levels after TURP in BPH patients and PSA level after TURP depends on various factors including pre-operative PSA and prostate volume; and prostate volume resected. There is a linear relationship between the different resection extent of TURP surgery and the declination in serum PSA. After complete TURP with benign histopathologic specimen, PSA should be expected to be within the normal reference range; mostly near the value of $1 \mathrm{ng} / \mathrm{ml}$. Serum PSA should be monitored at 3 months post TURP to assess the extent of resection of prostate.

\section{Declaration of conflict of interes}

This is one of rarest studies to evaluate fall in serum PSA following TURP. This study follows ethical guidelines. There is no conflict of interest and no source of funding involved in drafting this manuscript.

\section{List of Abbreviations}

BPH - Benign Prostatic Hyperplasia

TURP - Transurethral Resection of Prostate

PSA-Prostate Specific Antigen

TRUS - Transrectal Ultrasound

gms - grams

DRE - Digital Rectal Examination

mp-MRI - Multiparametric Magnetic resonance Imaging

\section{REFERENCES:-}

1. Aus G, Bergdahl S, Frosing R et al. Reference range of prostate - specific antigen after transurethral resection of the prostate. Urology 1996; 47(4):529-31.

2. Vesey SG, Goble NM, Stower MJ et al. The effects of Transurethral Prostatectomy on Serum Prostate Specific Antigen. British Journal of Urology 1988; 62:347-51.

3. Scattoni V, Raber M, Montorsi $F$ et al. Percent of free serum prostate specific antigen and histological findings in patients undergoing open prostatectomy for benign prostatic hyperplasia. Eur Urol 1999; 36:621-30

4. Roehrborn CG, Boyle P, Gould AL et al. Serum Prostate Specific Antigen as a predictor of prostate volume in men with Benign Prostatic Hyperplasia. Urology 1999; 53(3):581-9.

5. Stamey TA, Yang N, Hay AR et al. Prostate specific antigen as a serum marker for adenocarcinoma of the prostate. N Engl J Med 1987; 317:909-16.

6. Cho JS, Kin CL, Seong DH et al. Relationship between serum prostate- specific antigen and prostate volume in men with benign prostatic hyperplasia from multicentre study. Korean Journal of Urology 2005; 46(8):792-798.
7. Cho HJ, Shin CS, Cho MJ et al. The role of transurethral resection of the prostate for patients with an elevated prostate-specific antigen. Prostate Int 2014; 2(4): 196-202.

8. Park SC, Shin YS, Zhang LT et al. Prospective investigation of change in the prostate specific antigens after various urological procedures. Clinical Interventions in Aging specific antigens $2015 ; 10: 1213-18$.

9. Recker F, Kwiatkowski MK, Pettersson K et al. Enhanced expression of prostate specific antigen in the transition zone of the prostate. A characterization following prostatectomy for benign hyperplasia. Eur Urol 1998; 33(6):549-55.

10. Hosseini SY, Salimi M, Hosseini Moghaddam SM. Changes in Serum Prostate Specific Antigen Level after Prostatectomy in Patients with Benign Prostatic Hypertrophy. Uro Jour 2005; 2(4):183-88.

11. Won JJ, Chung HC, Song JM. The significance of changes in Serum Prostate Specific Antigen Levels after a Transurethral Resection of the Prostate. Korean Journal of Antigen Levels after a Tran

12. Fonseca RC, Gomes CM, Meireles EB et al. Prostate Specific Antigen Levels following Fonseca RC, Gomes CM, Meireles EB et al. Prostate Specific Antigen Leve
transurethral resection of the prostate. Int Braz J Urol 2008; 34(1):41-48.

13. Hasibuan Z, Wirjopranoto S, Djatisoesanto W et al. Difference in Serum PSA level and IIEF- 5 before and after TURP in BPH patients without Urinary Retention. Indonesian Journal of Urology 2012; 19(1).

14. Furuya Y, Akakura k, Tobe $T$ et al. Changes in serum prostate-specific antigen following prostatectomy in patients with benign prostate hyperplasia. International Journal of Urology 2000; 7:447-51.

15. Renterghem KV, Koeveringe GV, Achten R et al. Clinical relevance of Transurethral Resection of the Prostate in "Asymptomatic" Patients with an elevated ProstateSpecific Antigen Level. EUROPEAN UROLOGY 52 2007; 819-826.

16. Wolff JM, Boekels $\mathrm{O}$, Borchers $\mathrm{H}$ et al. Altered prostate specific antigen reference range after transurethral resection of the prostate. Anticancer Res 2000;20(6D): 4977-80.

17. Koeveringe VG, Renterghem KV, Achten R. Prospective study of the role of transurethral resection of the prostate in patients with an elevated prostate-specific antigen level, minor lower urinary tract symptoms and proven bladder outlet obstruction. Eur Urol 2008;54(6):1385-92

18. Liu J, Tang J, Gong D et al. Level change of prostate-specific antigen in patients with benign prostatic hyperplasia after transurethral prostatic resection. J Integr Nephrol Androl 2017; 4:10-3. 